\title{
Marketing Communications and Environmental Turbulence: A Complexity Theory View
}

\author{
Roger B. Mason \\ Durban University of Technology, South Africa \\ rogerm@dut.ac.za
}

\begin{abstract}
This paper investigates how the choice of different marketing communications activities is influenced by the nature of the company's external environment, when viewing the environment through a complexity theory lens. A qualitative, case method, using depth interviews, investigated the marketing communications activities in four companies in order to identify the promotional activities adopted in more successful firms in turbulent and stable environments. The results showed that the more successful company, in a turbulent market, subtly uses some destabilizing promotional activities but also makes use of some stabilizing promotional activities. This paper is of benefit by emphasizing a new way to consider promotional activities in companies.
\end{abstract}

\section{Keywords: Promotions, marketing communications, advertising, complexity theory, turbulence}

\section{Introduction}

A linear view of advertising predominated in the latter half of the twentieth century. Bovee et al. (1995) states that advertising followed a linear path with more emphasis on stabilization, as is indicated by some typical advertising functions: differentiate products from competitors, communicate product information, urge product use, expand product distribution, increase brand preference and loyalty and reduce overall sales costs. This is supported by Nilson (1995), who sees advertising and selling as traditional promotional tools, which he also maintains are the most stabilizing of promotional elements. The implication is that the traditional role of promotions is a stabilizing one. This deterministic view of advertising is consistent with Keynesian economics, which maintained that the role of advertising is to enable big companies to manage market demand by creating predictable consumer spending, i.e. to achieve stabilisation (Capra, 1982). Nilson (1995) further asserts that using advertising to create turbulence is contrary to the more traditional thinking of building long term brand loyalty and improving the image of the organization. In other words, marketing communication has traditionally been used as a stabilizing factor.

However, advertising is no longer seen to have such an influential, controlling and predictable role. The environment of global business is becoming extremely complex and has been experiencing unprecedented continuous, rapid change (Ahmed et al., 1996:562; Black \& Farias, 1997; Gilmore \& Pine, 1997:91; Doherty \& Delener, 2001:66; Burnes, 2005:73 and Yadav, Swami \& Pal, 2006:57). In such environments, markets are now known to be too complex for one factor, such as advertising, to produce predictable effects. The traditional, textbook concept of promotions discussed in the paragraph above is not consistent with the needs of a complex and turbulent environment. An ever-increasing number of authors believe that the new sciences, specifically chaos and complexity theories, can provide a better understanding of organizational and marketing environments (McKelvey, 2003:314; Van Uden, 2005:65; Wollin and Perry, 2004:569). Within this context of changing environment and the changing role of marketing communications, this study sets out to confirm, through the lens of the new sciences, if the role of marketing communications and the tactics used differ according to the turbulence or stability of the business environment, and whether a business's success is related to its use of promotional tactics (stabilising or destabilising) appropriate to their environment (turbulent or stable). First, complexity theory will be briefly defined, and then marketing communications tactics as suggested by the application of complexity theory to turbulent environments and the methodology used will be discussed. Thereafter empirical findings, implications and conclusions and recommendations are presented.

Complexity Theory: The underlying idea of complexity theory is that local interaction enables agents, elements or components to self-organize into systems. These systems develop patterns when simple rules are applied over many iterations, resulting in unexpected behaviours (Goldberg and Markoczy, 1998). Such unexpectedness is because of nonlinear feedback networks (Stacey, 1996), loosely coupled networks that produce order from the bottom up (Ritter et al., 2004) and the way the system's parts 
interact and adapt to each other (Meade and Rabelo, 2004). These interactions imply that business systems are "eco-systems" and therefore are difficult to manage. Their behaviour cannot be predicted, but can be influenced by encouraging relationships between system members (Baskin, 1998). From a promotional point of view, order and predictability is not possible, but co-construction of communications is necessary (Christensen, Torp and Firat, 2005). Several complexity concepts have relevance to marketing communications. The central concept is self-organization, the process of an orderly pattern emerging from a set of simple rules in an interconnected network. The process spontaneously self-organizes, bottom-up, through the inter-relationships of the system's parts (Smith, 2002; Holbrook, 2003), without a "manager" directing and controlling it (Wilkinson, 2006). Beekman and Wilkinson (2004) illustrate how self-organization in social insect behaviour can provide understanding of self-organization in advertising and selling activities. Self-organization encourages creative and innovative responses to emerge from changing environments (Dolan et al., 2003).

This emergence is the second complexity concept. It happens when the system's parameters change, leading to a movement towards disorder - important because too much order causes system ossification, but just enough disorder enables it to innovate and reorganize into new patterns of relationships, from which new actions emerge (Holbrook, 2003). In the longer term, what emerges is not predictable and therefore is not fully under the control of "management". Examples include new strategies (Conner, 1998) and tactics for specific prospects (Crosby, in Forrest and Mizerski, 1996). The third concept is feedback. Negative feedback pushes the system back to its original state, producing regular, predictable behaviour. Positive feedback amplifies changes, pushing the system away from equilibrium, towards instability (McGlone and Ramsey, 1998; Doherty and Delener, 2001). Together, positive and negative feedback balance the system at the "edge-of-chaos" (Wollin and Perry, 2004), the best position in a turbulent environment and where innovation and creativity is maximised, obviously of importance in advertising and promotions (Doherty and Delener, 2001). Positive feedback enables a firm with an early small advantage to grow exponentially until the advantage becomes "locked in", as happened with Microsoft Windows (Holbrook, 2003). Positive feedback has been shown in advertising by Stacey (1992) and Glass (1996).

The fourth important concept is sensitive dependence on initial conditions (SDIC) (Phillips and Kim, 1996). In a stable system, small changes have small effects, but in a complex adaptive system (CAS), small, seemingly unimportant, changes can produce surprisingly large effects (Holbrook, 2003; Wilkinson, 2006). SDIC suggests ways to cope in turbulent environments. Rather than dramatic controlling actions, small nudges at the correct time (the initial condition) can lead, through positive feedback, to major changes (Nilson, 1995). Being a "first mover" is essential, providing an advantage in the long-term (Koch, 2000). Although the future is unknowable, a successful first mover can influence, or "create", the future by recognizing the patterns that indicate which small changes to nudge and when to nudge them (Morrison and Quella, 1999). This is the basis of Nilson's (1995) destabilizing approach, especially regarding the use of sales promotion activities. Attractors, the fifth complexity concept, reflect the underlying order, structure or predictable patterns in a CAS (Wilkinson, 2006). The edge-of-chaos attractor, known as a "strange attractor", reflects the area where maximum creativity and innovation happens. A unique feature of the strange attractor is that behaviour always stays within certain boundaries (Holbrook, 2003). Behaviour is never identical within these boundaries, but is broadly predictable. Thus, change is permitted, while maintaining some order. Strange attractors have been illustrated in advertising (Feichtinger, Hommes and Milik (1994) and in customer behaviour (Herbig, 1990).

\section{Promotions and Complexity}

Marketing communications: The most common model of communication theory is illustrated by Figure 1. Marketing communications are generally also explained in terms of a similar model. Marketing communications has been defined as "a management process through which an organization enters into a dialogue with its various audiences" (Fill, 2002: 12). Most research into marketing communications to date has focused on conveying information , transferring a message and hierarchical sequence models such as AIDA (Finne and Grönroos , 2009). Varey (2004) sees this as focusing on the "how to", but maintains that the literature is silent on the "why", despite there being a critical need for such understanding. Schultz et al (2007) tried to answer this question, but failed to discover any theoretical basis that might be used as a foundation for understanding marketing communications. They found that the marketing communication literature focuses mainly at the applied and tactical level. Thus there is a need for research into marketing communications from a theory perspective rather than an applied or 
practical perspective, which this study addresses by investigating promotions from a complexity theory perspective.

\section{Figure 1: Model of communication}

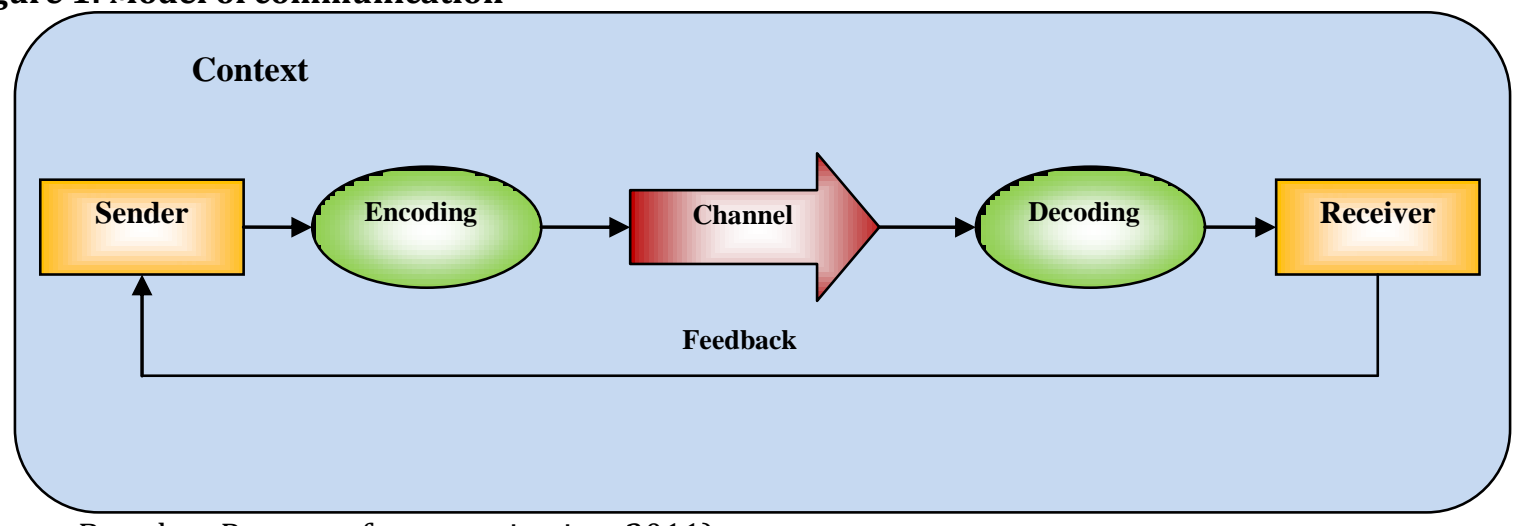

Source: Based on Process of communication, 2011)

Promotions and chaos/complexity theory: Chen and Wang (2008) have shown that advertising can exhibit chaotic behaviour, and Prendergast and Berthon (2000) maintain that a complexity or chaos perspective should be used to understand the dynamics of markets. According to Nilson (1995) marketing communications were, even fifteen years ago, important from a chaos viewpoint. Communications media were one of the fastest changing sectors of marketing, namely electronic highways, satellite communications, cable television, and, in addition to conveying a message, communications could be used to stabilize the marketing system. Although promotions are mostly stabilizing activities, they can also be destabilizing. However, they are unlikely to be able to achieve major, predictable disruptions in the marketplace, e.g. changing consumer attitudes and behaviours. Promotion can, however, encourage, or 'nudge', an already changing attitude or behaviour. Thus, a marketer can, through communications, speed up a change that has already started (Nilson, 1995). This is supported by Paladini (1999), who uses an example of a direct mail campaign to show how tiny improvements can be the difference between success, mediocrity or failure, and Stacey (1995), who gives an example of free trials leading to the unexpected consequence of a magazine going out of business. Priesmeyer (1992: 76), in a study of the novelty ice cream market, has shown how awareness of a market in chaos terms can help a marketer to adopt the most appropriate marketing tactics. This shows that knowing the attractor prevalent in a market enables the marketer to identify the appropriate marketing tactics. More aggressive promotional tactics in a turbulent market allow the alert marketer to take advantage of the turbulence to influence, or nudge, the trajectory of the attractor in order to increase market share, sales or profitability. The traditional types of promotions are media advertising, public relations, sales promotions and personal selling. These are discussed below in terms of their role from a chaos/complexity point of view.

Media advertising: De Vasconcellos (1991) found that in mature (and thus stable) industrial markets, advertising was of relatively little importance, but that with many customers and low risk of product malfunction, advertising might become more important. However, Feichtinger, Hommes and Milik (1994) imply that such an understanding is too simplistic. They found that a 'persistent firm' (meaning roughly, stable, conservative and relatively unchanging) stabilizes a situation by following a continuous and defensive advertising strategy. However, if such a persistent firm adopted an aggressive advertising strategy, then irregular and sometimes chaotic patterns resulted. In a less stable situation (rapidly decaying market share or turbulence) defensive advertising can lead to chaotic behaviour. Their study suggests that a firm in a more stable market would benefit from a continuous, conservative and defensive advertising strategy, typically image or institutional advertising, while a firm in a more turbulent market would benefit from a more aggressive, pulsed advertising campaign, typically product advertising (pioneering or competitive advertising). This indicates that advertising can be both stabilizing and destabilizing in its effects. Considering the stabilizing function of advertising, Herbig (1990: 72) found that if sales response and the loss of sales due to forgetting are fairly constant, then "fairly predictable stability ... can be achieved." In his analysis of advertising effectiveness, he found that publicity and advertising would be stabilizing. This is supported by Nilson (1995) who maintains that a large company could use advertising to minimize volatility. This works because the high costs of advertising can act as a barrier to entry, reducing competitive complexity and turbulence and by building brand loyalty, which is itself stabilizing. 
Some authors believe that advertising can also be destabilizing. According to Nilson (1995: 92) there are three ways in which this can be achieved.

- The first method is to hijack another company's brand reputation to establish one's own brand. This is often done through some form of comparative advertising, whereby the challenger encourages the consumer or customer to view the new or 'inferior' brand as equivalent to the brand leader. This also has the advantage for the challenger of moving the perceptions of the consumer away from brand building intangibles (stabilizing dimensions) to product features, which potentially can create more volatility.

- The second approach is to launch a totally new and shocking, or amazing, advertising campaign. The controversy generated can result in unexpected customer behaviour. Dru (1996) agrees, believing that advertising can be a tool for disruption, or destabilization, by taking both a creative and a strategic leap from the present into the future. Herbig (1990) maintains that chaos, and thus unpredictability of results, could result from overspending on advertising.

- The third approach is more conservative but requires excellent creativity to shift the perceptions of the market, changing the rules of the game. This involves an unexpected campaign, such as Volkswagen's advertisements which changed the way consumers thought about motor cars - from "chrome and oversized engines to utility and practicality" (Nilson, 1995: 93).

Personal selling: In a smaller company that cannot afford the high costs of media advertising, emphasis on personal selling and relationship building can act as a stabilizing factor. Through sound salespersonbuyer relationships, the customers can be encouraged to remain loyal to the supplier (Nilson, 1995). Personal selling, because of its personal dialogue, can create "a dominating position in the minds of the customers," and because of this it is a stabilizing influence on a market. However, the relationship should be tied directly to the company, and not to the individual sales representative. Furthermore, the sales force can play a key role as a feedback loop between customer and company. Flexibility and the ability to act at a quicker pace are possible using the networks of relationships with suppliers, distributors and customers. Strong marketing knowledge is needed by the sales force, especially in mature and stable markets to achieve this (De Vasconcellos, 1991). This highlights the importance of personal selling in stable and simple environments.

Public relations (PR): Much of what has been said about personal selling is true of public relations, as PR also emphasizes relationship building and could thus be stabilizing. Herbig (1990) implies that PR is a more stabilizing element and Nilson (1995) agrees that it can be a very effective method of disseminating information and building loyalty. Gürel and Kavak (2010) see complexity theory as a suitable framework for public relations. In chaos theory terms, through a relatively small and inexpensive PR activity - a 'nudge' - significant outcomes can result because of the multiplier effect. However, like all activities based on sensitive dependence on initial conditions, the result is unpredictable. Although the instigator of the action hopes for a positive response, they have no control over the dissemination of the information, nor over the way is the message presented.

Sales promotion: According to Nilson (1995), sales promotion activities, when linked to price promotions, create instability in a market and thus are destabilizing. The more unusual the promotion the greater the likelihood of the outcome being different to what was expected, that is, if the market is in a chaotic state an unpredictable outcome might be expected. However, when the sales promotion follows a theme (such as competitions, cross promotions, etc.) it can stabilize the system (Nilson, 1995). Promotions that build relationships have the same stabilizing effects as advertising. Direct marketing, via a database, which builds a relationship with customers through personalized communications, can also be stabilizing. It is more difficult for competitors to disrupt this communications method. Rapid changes in the technological environment have enabled sales promotions, through computerization, scanning and smart cards, to stabilize the marketing system by developing loyalty programs. Priesmeyer (1992) suggests different tactics for different market, namely stabilizing sales promotion in a low order chaos market and destabilizing sales promotions in the high order chaos market. This shows that aggressive sales promotional tactics are relevant in a turbulent market. This is indirectly supported by Williams (1994) who reported that sales promotion as a percentage of the marketing budget increased from about $10 \%$ in the relatively stable 1980 s, to as much as $65 \%$ in the more turbulent early 1990 s. The implication is that, in a rapidly changing marketing environment, sales promotion is a more effective marketing tool than advertising and should be used to cope with the increasingly turbulent market. 
Word of mouth: Herbig (1990: 75) found a relationship between word of mouth advertising and chaos, resulting in word of mouth being seen as destabilising, and Mason (2008) found word of mouth to be effective in turbulent environments. In other words, positive word of mouth promotional activities that encourage talking about the company or product should be used. Each activity, small and relatively unimportant in itself, could escalate through word of mouth to create strong and positive, or negative, brand images and beliefs. The principles of sensitive dependence on initial conditions or the 'nudge' effect are at work here. Nilson (1995: 159) stresses that word of mouth has a very strong non-linear effect and is impossible to control. It is more relevant in turbulent, high technology markets because they have little time to build brand image because of their short product life cycles (Smith et al., 1999: 646; Mohr, 2001: 285). Mohr (2001: 343) suggests the use of viral marketing to rapidly spread word of mouth. Word of mouth is therefore a very effective tactic for use in an environment that is at the edge of chaos. In conclusion, it can be seen that some promotions or communications can have a destabilizing influence, but that all can have a stabilizing influence. Nilson (1995: 133) maintains that "advertising and personal selling have the strongest [stabilizing] effects." This is so because they act directly on the marketing system and because the consistency of execution in a good thematic campaign creates extra stability. In a world of thousands of media messages bombarding the consumer daily, the familiarity of a consistent theme is important. Consequently, stability in a constantly moving environment can be a positive characteristic for the consumer.

Proposed Promotional Tactics: Summarising the findings of the above literature review, and viewing them through the complexity lens, enabled a model to be developed of what promotional activity could be expected of a successful company in a complex/turbulent market, and a second model of what promotional activity could be expected of a successful company in a stable/simple market (Mason, 2004; Mason and Staude, 2009). The model for the turbulent market is presented in Table 1, while Table 2 presents the model for a stable market. Based on these two models, four propositions were developed to explore the use of promotional tactics in the two environmental extremes, as follows:

P1. A more successful company in a complex/turbulent environment uses more destabilizing marketing tactics.

P2. A less successful company in a complex/turbulent environment uses more stabilizing marketing tactics.

P3. A more successful company in a simple/stable environment uses more stabilizing marketing tactics.

P2. A less successful company in a simple/stable environment uses more destabilizing marketing tactics.

\section{Methodology}

Research design: The lack of research in the specific field (Smith, 2002) dictated the need for an exploratory study, as is supported by Mitleton-Kelly's (2003: 3) argument for "a deeper understanding of complex systems." Some authors suggest that, because chaos is a mathematical theory, a quantitative methodology is required. However, others stress the importance of metaphors for theory formulation, seeing new connections and for generalizing across contexts (Smith, 2002; Wilkinson, 2003). These arguments highlight the need for a qualitative approach. The method chosen for the study was the case method to enable the problem to be studied intensively (Welman and Kruger, 1999). To improve the rigor of the study a comprehensive research protocol was developed (Yin, 2003). Although much research in the chaos and complexity fields is done via simulations, very little research is done using real data. Therefore, research that uses real data, albeit qualitative, as this study does, is an important contribution to knowledge about marketing from a complexity theory viewpoint.

Respondent sampling: Maximal variation sampling was used to select the case companies. This method strives "to integrate only a few cases, but those which are as different as possible, to disclose the range of variation and differentiation in the field" (Flick, 1998:70). The sample was selected through a two-stage process:

- The most and least complex/turbulent industries were identified via a questionnaire completed by six experts (stock brokerage industry analysts and management consultants). It questioned the experts on the complexity and turbulence in seven external environment sub-categories in nineteen industries. The Information Technology (IT) industry was identified as the most complex/turbulent and the packaging industry as the least.

- Within each of these two industries, a more successful and a less successful company was selected, based on a Delphi process (Roberts, 2000), using panels of four experts specializing in the IT and packaging industries (consultants, journalists and buyers). A two-iteration, ranking process of the more successful and less successful companies resulted in the panellists nominating ITA and ITB as 
the more and less successful IT companies, and PA and PB as the more and less successful packaging companies, respectively.

Data collection: Data was collected via semi-structured focused depth interviews (Yin, 2003) because they provide deeper understanding, allowing patterns and connections to emerge, which provide insights. "Interviewees are not seen as an average sample ...but as fractal representatives of the whole" (MitletonKelly, 2003:5). Interviews were conducted with a total of thirty-one CEOs, directors, managers and marketing and sales staff in the four companies. All thirty-one met Morse's criteria for being good informants (Flick, 1998). To obtain co-operation, anonymity was promised. Interviews took about an hour each, were based on an interview guide and were audiotape recorded and, in addition, notes were taken. In addition, various company documents were analyzed, for example, annual reports, brochures, web pages, advertisements, meeting minutes and policy manuals.

Data analysis: A combination of techniques was used to analyze the material. Thematic coding, using NVIVO software, was used to deconstruct and reconstruct the transcripts to categorize findings according to the perspective being studied (more/less successful). Each code, and its associated set of extracts, was manually analyzed, looking for patterns of similarities and differences in the themes or initial codes. These 'pattern codes' constituted the themes, causes/explanations and relationships that are discussed in the findings section of this paper. Content analysis was used to paraphrase, summarize and reduce the field note data and the documents to generalizations in order to compare them with the propositions. This material was summarized into tables to compare the four companies against each other, and against the propositions.

Validity and reliability: 'Method-appropriate criteria' and multiple data collection methods, namely data triangulation, methodological triangulation, prolonged engagement and an audit trail, validated the procedures, increasing rigor and trustworthiness (Flick, 1998). Construct validity was increased by using multiple data sources, internal validity was increased by comparison and pattern matching across the cases, external validity was increased by using cross-case analysis of multiple cases (thereby allowing some generalization), and reliability was increased by using a data collection protocol and keeping a data base of the empirical data and a chain of evidence (Yin, 2003). This method adhered to the ten design considerations of Lincoln and Guba, and thus met the criteria for a high quality, rigorous and trustworthy study (Rudestam and Newton, 1992).

\section{Findings}

As shown by the literature, promotion can be either a stabilizing or a destabilizing tactic, and this section considers the broad promotional categories, and the extent to which the researched companies use them to stabilize or destabilize their markets.

Turbulent and complex environment: Neither company in the information technology industry makes much use of the traditional promotional mix. The main tactics used are personal selling or public relations. The main public relations activities of both companies are events that bring them together with their customers, such as sports days, cocktail parties, exhibitions or luncheon meetings. ITA focus on publicity, news releases and on entertainment events such as golf days that they sponsor, and other sporting events, while ITB seem to use whatever opportunities present themselves, in a rather unfocussed way. Media advertising is not used at all by ITB, and only to a limited extent by ITA, with some corporate image advertising and some advertising in support of their sponsorships. Sales promotions are not used by either company. Personal selling, via sales representatives for ITA and senior executives for ITB, is a critical component of both companies' promotional activities. The one promotional method that both companies feel is the most important is word of mouth advertising, which is very effective when considered from a chaos theory perspective. The concept of sensitive dependence on initial conditions (or Nilson's (1995) 'nudge' effect or Gladwell's (2000) 'tipping point') shows that small initial actions, such as positive comments from a satisfied customer, can spread exponentially through 'word of mouth' resulting in a promotional effect much greater than the initial comment. Neither company has formalized their promotional activities in order to encourage word of mouth. They are, however, aware of the fact that activities such as referrals, entertaining at sports events and use of clients as spokespersons, do generate word of mouth. ITA's awareness of this appears to be higher, and they do more to encourage customers to talk about their service and to recruit potential customers. Although ITA appears to be more aggressive in the use of their promotional tactics than ITB, both companies use their promotional 
activities to strengthen their relationships with customers. ITA's promotional activities, although not seen as destabilising, could have the effect of shaking loose the connections between prospective customers and competitive suppliers, and as such they do, subtly, use promotional activities to destabilise. ITB's promotional activities lack of variability, which is consistent with a stabilizing approach - destabilizing policies would tend to change activities before the market became used to them or before they could react to them. Keeping promotional activities the same enables customers to get used to them, to become comfortable with the company - in other words a stabilizing approach.

From the above discussion it can be seen that the promotional tactics used by ITB are consistent with what could be expected of a less successful company in a turbulent and complex environment. Those few promotional tactics that they do use are all of a more stabilizing nature. ITA also use their promotional tactics in a stabilizing way, which is contrary to what is expected of a more successful company in a turbulent and complex environment. However, they also use their promotional tactics to destabilize the market. Such destabilizing activities could be seen to make potential customers dissatisfied with their current suppliers and aware of ITA as an alternative supplier.

Thus, although there are many similarities in the way that the two companies apply their promotional tactics, there is sufficient difference, albeit subtle, to conclude that the use of promotional tactics was found to be as anticipated in the propositions.

Stable and simple environment: The two companies in the packaging industry are very similar in terms of the use of promotional tactics. Both make little use of promotions, concentrating mostly on personal selling, public relations and word of mouth in order to merely spread their name in the industry. Promotions are not used at all to disrupt the market, although PA are quite prepared to shake the market up by doing other things differently or setting standards that are way ahead of the industry norm. The types of promotional activities that they do undertake are very standard, low key, and the minimum to be expected of such companies. No evidence of aggressive or disruptive promotional activities was found. They both see public relations activities as important. Much of their public relations activities revolve around entertainment and networking, but it does not seem to be planned with any specific objectives in mind. PA emphasizes the speed of their services and their numerous awards, while PB focuses on reminding customers of the company. Although seen as rather unimportant, both companies do use media advertising on a limited and ad hoc basis. Neither company makes use of sales promotional activities, but both do use personal selling, and see it as very important. Both companies have sales representatives who are knowledgeable about their customers and the market, and who are involved in important company meetings. For both companies the promotional tool that is most important and used the most is word of mouth. Although important, neither company seems to do anything proactively to encourage it. Activities that they believe because word of mouth is mostly public relations type activities. PA maintains that their promotions are changed regularly, which is consistent with PA's innovative and novel approaches. Regarding PB, their promotional activities are fairly standard, and do not seem to change much over time. The promotional activities of the two companies are very similar. Both companies rely on personal selling, public relations and word of mouth, while making little or no use of advertising and sales promotions. Their attitudes towards, and objectives of, promotions are also the same. What little difference there is, lies in the details of the activities undertaken, and can be considered insignificant in terms of the influence on success. Most of the findings were consistent with what was expected of a more successful company in a stable and simple environment. The exceptions were the importance placed on word of mouth (but not overly encouraged) by PA and the importance of sales representatives by PB. Since these two factors seem to be so important, it can be concluded that PA performed approximately as expected of a more successful company in a stable and simple market, with PB not performing as would be expected of a less successful company.

Discussion of Results: The discussion above shows that promotions are important in both complex/turbulent and simple/stable environments, but for different reasons, and different types of promotional activities are important in the different environments. In the complex/turbulent environment, aggressive sales promotions (linked to price promotions) and word of mouth advertising are effective, while in simple/stable environments image advertising and personal selling are more effective. In both environments public relations and sales promotions can be effective, but applied in different ways. The empirical results, as summarized above, were compared against the two models resulting from the literature review. This comparison for the complex and turbulent market, namely the 
information technology market, is reflected in Table 1 and the comparison for the stable and simple market, namely the packaging market, is reflected in Table 2.

Table 1: Comparison of companies against complex/turbulent environment model

\begin{tabular}{|c|c|c|c|c|c|}
\hline Tactic & Model 1 & Company ITA & Match & Company ITB & Match \\
\hline $\begin{array}{l}\text { Public } \\
\text { relations }\end{array}$ & $\begin{array}{l}\text { Although less important, small PR } \\
\text { activities can nudge the system } \\
\text { towards destabilization }\end{array}$ & $\begin{array}{l}\text { Extensive use, eg } \\
\text { client events \& press } \\
\text { publicity - formally } \\
\text { planned. }\end{array}$ & No & $\begin{array}{l}\text { Limited use of } \\
\text { customer events, in } \\
\text { unfocussed way }\end{array}$ & Yes \\
\hline $\begin{array}{l}\text { Media } \\
\text { advertising }\end{array}$ & $\begin{array}{l}\text { Pulsed, pioneering, competitive. } \\
\text { Product, comparative ads disrupt } \\
\text { consumers' beliefs about } \\
\text { competitors. Shocking or amazing } \\
\text { ads create controversy, shift } \\
\text { perceptions, change 'rules'. }\end{array}$ & 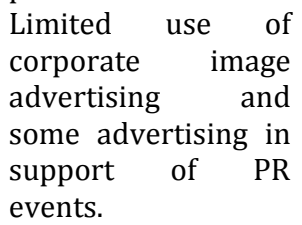 & No & Not used & No \\
\hline $\begin{array}{l}\text { Sales } \\
\text { promotions }\end{array}$ & $\begin{array}{l}\text { Use with price promotion - can } \\
\text { destabilize, especially if unusual. } \\
\text { Minor changes can lead to major } \\
\text { impacts. Better than advertising in } \\
\text { turbulent markets. }\end{array}$ & Not used & No & Not used & No \\
\hline $\begin{array}{l}\text { Personal } \\
\text { selling }\end{array}$ & $\begin{array}{l}\text { Although obviously needed, is seen } \\
\text { as relatively unimportant for } \\
\text { destabilizing in turbulent market }\end{array}$ & $\begin{array}{l}\text { Critical, but not as } \\
\text { knowledgeable as } \\
\text { they should be. }\end{array}$ & No & $\begin{array}{l}\text { Critical to success, } \\
\text { with reps very } \\
\text { knowledgeable }\end{array}$ & No \\
\hline $\begin{array}{l}\text { Word of } \\
\text { mouth } \\
\text { (WoM) }\end{array}$ & $\begin{array}{l}\text { Continuously encourage WoM. } \\
\text { 'Influence-the-influencer' } \\
\text { promotions, eg free or low priced } \\
\text { products for opinion leaders. } \\
\text { Spread info about amazing aspects } \\
\text { of product, use multiplier channels } \\
\text { like Internet }\end{array}$ & $\begin{array}{l}\text { Very important. } \\
\text { Aware of role } \\
\text { promotions can take } \\
\text { in promoting it and } \\
\text { do try to generate it, } \\
\text { but such promotion } \\
\text { not formalized. }\end{array}$ & Yes & $\begin{array}{l}\text { Very important. } \\
\text { Aware of role } \\
\text { promotions can take } \\
\text { in promoting it and } \\
\text { do try to generate it, } \\
\text { but such promotion } \\
\text { not formalized. }\end{array}$ & Yes \\
\hline $\begin{array}{l}\text { Aggressive } \\
\text { use of } \\
\text { promotions }\end{array}$ & $\begin{array}{l}\text { Aggressive use enables trends to be } \\
\text { nudged and advantage to be taken } \\
\text { of turbulence }\end{array}$ & $\begin{array}{l}\text { Aware of role in de. } \\
\text { Used subtly, but not } \\
\text { aggressively. }\end{array}$ & Partial & $\begin{array}{l}\text { Not aggressive, } \\
\text { although think it } \\
\text { might be good idea. }\end{array}$ & No \\
\hline $\begin{array}{l}\text { Speed of } \\
\text { change of } \\
\text { promotions }\end{array}$ & $\begin{array}{l}\text { To be unusual and surprising, } \\
\text { campaigns should be short-term, } \\
\text { and changed frequently. }\end{array}$ & $\begin{array}{l}\text { Promo activities not } \\
\text { changed much, so } \\
\text { seem slow to change. }\end{array}$ & No & $\begin{array}{l}\text { Promo activities not } \\
\text { changed, so seem } \\
\text { slow to change. }\end{array}$ & No \\
\hline $\begin{array}{l}\text { Importance } \\
\text { of } \\
\text { promotion }\end{array}$ & $\begin{array}{l}\text { Are important to manage the } \\
\text { system via nudge effect, but less } \\
\text { effective in making major changes }\end{array}$ & $\begin{array}{lr}\text { Not seen as very } \\
\text { important } \\
\text { general. }\end{array}$ & Partial & $\begin{array}{l}\text { Generally seen as } \\
\text { less important - } \\
\text { used to the market }\end{array}$ & No \\
\hline
\end{tabular}

Table 1 shows that ITA has a weak match to the model with regard to their promotional tactics. Five ' $n o$ 's', two 'partials' and only one 'yes' indicating a poor match to the model. Therefore, ITA performs like a less successful company in terms of their promotional tactics. In other words, they tend to use promotional tactics to stabilize their market rather than to create instability. It was expected that ITB's promotional tactics would not match Model 1 very closely. A perfect mismatch would be shown by eight ' $n o$ 's' in the last column, which summarizes the comparisons. The six 'no's' and two 'yeses' in Table 1 indicate that ITB's approach to promotional tactics do not match Model 1 very closely, as expected. In other words they tend to use promotions to stabilize, as proposed. Thus Proposition 1 cannot be accepted, but Proposition 2 can be partially accepted.

Table 2: Comparison of companies against simple/stable environment model

\begin{tabular}{lllllll}
\hline Tactic & Model 2 & Company PA & Match & Company PB & Match \\
\hline Media & Conservative, defensive & Unimportant & No & Unimportant & No \\
advertising & institutional or image adverts. limited and ad & & limited and ad & \\
& Act as barrier to entry and build hoc in trade & & hoc in trade \\
& brand loyalty. Heavy spending journals and & & journals & and \\
& reduces importance of rest of directories. & & directories.
\end{tabular}

Personal Strong customer-rep Very important. Yes selling relationships, by keeping Knowledgeable

customer loyalty. Good rep reps. knowledge
Very important. Yes

Knowledgeable

reps. 


\begin{tabular}{|c|c|c|c|c|c|}
\hline $\begin{array}{l}\text { Public } \\
\text { relations }\end{array}$ & $\begin{array}{l}\text { Important for providing info to } \\
\text { help build customer loyalty, } \\
\text { strengthen relationships, and } \\
\text { thus stabilize situation }\end{array}$ & $\begin{array}{lr}\text { Important } & - \\
\text { entertain } & \& \\
\text { network with } & \\
\text { customers, but } \\
\text { unfocussed, }\end{array}$ & Yes & $\begin{array}{lr}\text { Important } & - \\
\text { entertain } & \& \\
\text { network } & \text { with } \\
\text { customers but } \\
\text { unfocussed, } \\
\text { unplanned. }\end{array}$ & Yes \\
\hline $\begin{array}{l}\text { Sales } \\
\text { promotions }\end{array}$ & $\begin{array}{l}\text { Stabilizing when themed, build } \\
\text { relationships - direct marketing } \\
\text { \& personal communications - } \\
\text { quick feedback, difficult to } \\
\text { disrupt- eg loyalty programs, } \\
\text { smart cards }\end{array}$ & Not used & No & Not used. & No \\
\hline $\begin{array}{l}\text { Word of } \\
\text { mouth } \\
\text { (WoM) }\end{array}$ & $\begin{array}{l}\text { Always important, but not as } \\
\text { effective in stable market, due } \\
\text { to fewer network links, innate } \\
\text { conservatism, and less dramatic } \\
\text { issues to generate interest. }\end{array}$ & $\begin{array}{l}\text { Very important, } \\
\text { but not proactive. } \\
\text { Aware of PR } \\
\text { activities that } \\
\text { encourage it. }\end{array}$ & Partial & $\begin{array}{l}\text { Very important, } \\
\text { but not } \\
\text { proactive. Aware } \\
\text { of PR activities } \\
\text { that encourage it. }\end{array}$ & Partial \\
\hline $\begin{array}{l}\text { Aggressive } \\
\text { use of } \\
\text { promotions }\end{array}$ & $\begin{array}{l}\text { Promotions more conservative } \\
\text { and used to build and maintain } \\
\text { relationships, i.e. not aggressive. }\end{array}$ & $\begin{array}{l}\text { Conservative, low } \\
\text { key, not } \\
\text { disruptive, } \\
\text { relationship } \\
\text { building }\end{array}$ & Yes & $\begin{array}{l}\text { Conservative, } \\
\text { low key, not } \\
\text { disruptive, } \\
\text { relationship } \\
\text { building }\end{array}$ & Yes \\
\hline $\begin{array}{l}\text { Speed of } \\
\text { change of } \\
\text { promotions }\end{array}$ & $\begin{array}{l}\text { Promotions longer-term, } \\
\text { themed \& thus not changed too } \\
\text { quickly - allow market to build } \\
\text { relationship with campaign }\end{array}$ & $\begin{array}{l}\text { Changed } \\
\text { regularly. Do not } \\
\text { keep same } \\
\text { promotions over } \\
\text { time. }\end{array}$ & No & $\begin{array}{l}\text { Kept standard } \\
\text { and not changed } \\
\text { much over time. }\end{array}$ & Yes \\
\hline $\begin{array}{l}\text { Importance } \\
\text { of } \\
\text { promotions }\end{array}$ & $\begin{array}{l}\text { Important for stability by } \\
\text { building relationships, loyalty \& } \\
\text { countering competitors' } \\
\text { disruptive actions }\end{array}$ & $\begin{array}{l}\text { Unimportant. } \\
\text { Only to spread } \\
\text { company name in } \\
\text { industry. }\end{array}$ & No & $\begin{array}{l}\text { Unimportant. } \\
\text { Only to spread } \\
\text { company name } \\
\text { in industry. }\end{array}$ & No \\
\hline
\end{tabular}

Table 2 shows that PA has a partial match to the model with regard to their promotional tactics. Four 'no's', three 'yeses' and one 'partial' indicate that PA perform partly like a less successful company and partly like a more successful company in terms of their promotional tactics. It was expected that PB's promotional tactics would not match Model 2 very closely. The comparisons in Table 2 indicate that PB's approach to promotional tactics matches Model 2 fairly closely. The four 'yes's, three 'no's' and a 'partial' indicate a weak to fair match to what was expected. Thus, neither Proposition 3 nor 4 can be fully accepted.

Implications for Marketers: The above discussion suggests that marketing managers could benefit from this study by using the chaos and complexity principles to guide their marketing mix development. In turbulent markets, provision should be made to use promotional activities to destabilize the market in order to maximize opportunities to win new customers and gain market share, but allowance should also be made to use promotions for stabilizing the relationships with existing customers to maintain customer loyalty. Thus, marketers should be prepared to use their promotional activities for both stabilizing and destabilizing tactics.

Destabilizing actions: If the firm is financially strong enough, pioneering, product advertising should be used with a shocking or amazing campaign aimed at shifting perceptions about the firm or the product. If allowed, comparative advertising can be disruptive. Creative and unusual sales promotion campaigns should be used especially linked to price promotions. Even small, localized campaigns can be effective in promoting instability - for example, between a specific competitor and its customers. These promotional programs should be aggressive, deliberately aimed at destabilizing competitors' relationships. Furthermore, they must not be allowed to become expected or stale - they should be changed frequently to maintain the unexpected and surprising. The empirical findings emphasized the importance of word of mouth in complex and turbulent markets. Therefore, firms should continuously take actions to encourage the spread of word of mouth. Such actions can include influence-the-influencer actions such as giving free or low priced products to opinion leaders, spreading information about amazing product facts through 
multiplier media such as the Internet, or matching satisfied customers with potential customers at entertainment events.

Stabilizing actions: Although it is necessary to destabilize the market, it is also necessary to stabilize the relationships with customers so that the volatility does not result in the disruption of the firm's own relationships with loyal customers. Actions that can achieve this are strong sales force activities aimed at building and maintaining sound customer relationships. Certain types of sales promotions can be used to maintain customer loyalty. Direct marketing and personalized communications, with a stable theme can be used to maintain relationships and support loyal customers. Smart cards, loyalty programs and, of course, excellent service would form part of a stabilizing campaign.

\section{Limitations and Recommendations}

Limitations: Since this was an exploratory study and a small sample was used, it is subject to the limitations of small sample studies, namely that the findings are not necessarily representative of all companies in the sampled industries, nor are they necessarily representative of similar types of environments. Furthermore, the use of maximal variation sampling, i.e. the choice of only two industries, makes it difficult to draw conclusions about other industries. In other words, the degree of variation between other industries might not be so significant, and therefore it might be inaccurate to try to apply these findings to other industries. Therefore, if extrapolation of the results to other industries is attempted it should be done with extreme caution.

Recommendations for further research: Resolution of the above problems and expansion of knowledge of promotional tactics could be achieved through successful research in some of the following areas:

- Similar research, but in a wider range of companies and in different industries, could test whether the findings of this study can be generalised to other industries and countries.

- Quantitative research focussing on a specific industry could be very helpful in more clearly differentiating the promotional tactics of more successful from less successful companies.

- This study concentrated on the total promotional mix. More detailed research into individual promotional activities from a chaos and complexity perspective could throw considerable light on their role in stabilising or destabilising the market, and on their influence on marketing success.

- Of major benefit would be a longitudinal study that follows the trajectory of a promotional tactic or campaign to see how it develops according to the principle of sensitive dependence on initial conditions. This would confirm whether complexity and chaos theories are truly helpful in understanding marketing communications.

\section{References}

Ahmed, P. K., Hardaker, G. \& Carpenter, M. (1996). Integrated Flexibility - Key to Competition in a Turbulent Environment. Long Range Planning, 29(4), 562-571.

Baskin, K. (1998). Corporate DNA: Learning from life. Boston: Butterworth-Heinemann.

Beekman, M. \& Wilkinson, I. F. (2004). What can social insects teach us about marketing? Paper presented at Australia New Zealand Marketing Academy Annual Conference, Wellington, December.

Black, J. \& Farias, G. (1997). Genesis of Complexity Cycles, paper read at Eighth Annual International Conference of The Society for Chaos Theory in Psychology \& Life Sciences, Boston University, Boston, 31 July.

Bovee, C. L., Thill, J. V., Dovel, G. P. \& Wood, M. B. (1995). Advertising Excellence. New York: McGraw-Hill.

Burnes B. (2005). Complexity theories and organizational change. International Journal of Management Reviews, 7(2), 73-90.

Capra, F. (1982). The Turning Point: Science, society and the rising culture. London: Flamingo.

Cespedes, F. V. (1996). Beyond Teamwork: How the Wise can Synchronize. Marketing Management, 5(1), 24-37.

Chen, L. \& Wang, X. (2008). Controlling chaos in a duopoly advertising model. Dynamics of Continuous, Discrete and Impulsive Systems Series B: Applications \& Algorithms, 15, 327-337.

Christensen, L. T., Torp, S. \& Firat, A. F. (2005). Integrated marketing communication and post modernity: an odd couple? Corporate Communications, 10(2), 156-167.

Conner, D. R. (1998). Leading at the Edge of Chaos: How to Create the Nimble Organization. New York: John Wiley. 
D'Aveni, R. A. (1999). Strategic supremacy through disruption and dominance. Sloan Management Review, 40(3), 127 - 135.

De Vasconcellos, J. A. S. (1991). Key Success Factors in Marketing Mature Products. Industrial Marketing Management, 20, 263-278.

Doherty, N. \& Delener, N. (2001). Chaos Theory: Marketing and Management Implications. Journal of Marketing Theory and Practice, 9(4), 66-75.

Dolan, S. L., Garcia, S. \& Auerbach, A. (2003). Understanding and Managing Chaos in Organisations. International Journal of Management, 20(1), 23-35.

Dru, J. M. (1996). Disruption: Overturning Conventions and Shaking Up the Marketplace. New York: Wiley.

Feichtinger, G., Hommes, C. H. \& Milik, A. (1994). Complex dynamics in a threshold advertising model. OR Spektrum, 16, 101-111.

Finne, Å. \& Grönroos C . (2009). Rethinking marketing communication: From integrated marketing communication to relationship communication. Journal of Marketing Communications, 15(2-3), 179-195

Flick, U. (1998). An Introduction to Qualitative Research. London: Sage.

Forrest, E. \& Mizerski, R. (1996). Interactive Marketing: The Future Present. Lincolnwood: NTC Business Books.

Gilmore, J. H. \& Pine II, B. J. (1997). The Four Faces of Mass Customization. Harvard Business Review, 2, 91-101.

Gladwell, M. (2000). The Tipping Point: How little things can make a big difference. London: Abacus.

Glass, N. (1996). Chaos, Non-linear Systems and Day-to-day Management. European Management Journal, 14(1), 98-105.

Goldberg, J. \& Markoczy, L. (1998). Complex Rhetoric and Simple Games [online]. Cranfield University. Available at: www.Cranfield.ac.za/public/cc/cc047/papers/ complex/html /complex.htm, [Accessed 2nd February 1999].

Gürel, E. \& Kavak, B. (2010). Commentary: A conceptual model for public relations in museums. European Journal of Marketing, 44(1/2), 42-65

Herbig, P. A. (1990). Marketing chaos - when randomness can be deterministic. Journal of International Marketing and Market Research, 16(2), 65-84.

Heyward, S., Spungin, J. \& Turnbull, D. (2007). Cracking the complexity code. The McKinsey Quarterly, 2, 85-95.

Holbrook, M. B. (2003). Adventures in Complexity: Dynamic Open Complex Adaptive Systems, Butterfly Effects, Self-Organizing Order, Co-evolution, the Ecological Perspective, Fitness Landscapes, Market Spaces, Emergent Beauty at the Edge of Chaos, and All That Jazz [online]. Academy of Marketing Science Review, 6. Available at: www.amsreview.org/articles/holbrook06-2003.pdf, [Accessed 2nd February 2006].

Jager, W. (2007). The four P's in social simulation, a perspective on how marketing could benefit from the use of social simulation. Journal of Business Research, 60, 868-875.

Koch, R. (2000). The Power Laws - The Science of Success. London: Nicholas Brealey.

Mason, R. B. (2004). An investigation into how marketers cope with an environment of high complexity and turbulence, with special reference to the South African environment. Unpublished PhD thesis, Rhodes University, Grahamstown.

Mason, R. B. (2008). Word of mouth as a promotional tool for turbulent markets. Journal of Marketing Communications, 14(3), 207-224,

Mason, R. B. \& Staude, G. (2009). An exploration of marketing tactics for turbulent environments. Industrial Management \& Data, Systems, 109(2), 173-190.

McGlone, T. A. \& Ramsey, R. P. (1998). Getting Realistic about Reality: Using Chaos Theory to Explain Marketing Phenomena. Proceedings of Society for Marketing Advances conference, New Orleans, 4-7 November 1998.

McKelvey, B. (2003). Towards a complexity science of entrepreneurship. Journal of Business Venturing, 19 , 313-341.

McLuhan, M. (1964). Understanding Media: The Extensions of Man. London: Abacus.

Meade, P. T. \& Rabelo, L. (2004). The technology adoption life cycle attractor: Understanding the dynamics of high-tech markets. Technological Forecasting and Social Change, 17, 667-684.

Mitleton-Kelly, E. (2003). Complexity research - approaches and methods: the LSE complexity group integrated methodology. Available at: www.psych.lse.ac.uk/complexity/publications.html [Accessed May 2, 2008].

Mohr, J. (2001). Marketing of High-Technology Products and Innovations. Upper Saddle River: Prentice Hall. 
Morrison, D. J. \& Quella, J. A. (1999). Pattern thinking: Cutting Through the Chaos. Marketing Management, 8(4), 17-23.

Nilson, T. H. (1995). Chaos Marketing: How to win in a turbulent world. London: McGraw-Hill.

Paladini, M. (1999). Changes need not be big to create a big result. Marketing News, 18 Jan., 4.

Phillips, F. \& Kim, N. (1996). Implications of Chaos Research for New Product Forecasting. Technological Forecasting and Social Change, 53(3), 239-261.

Prendergast, G. \& Berthon, P. (2000). Insights from Ecology: An Ecotone Perspective of Marketing. European Management Journal, 18(2), 223 - 231.

Priesmeyer, H. R. (1992). Organizations and Chaos: defining the Methods of Nonlinear Management. Westport: Quorum Books.

Process of communication. (2011). Available at: http://www.mbaknol.com/businesscommunication/process-of-communication/ [Accessed August 17, 2011].

Ritter, T., Wilkinson, I. F. \& Johnston, W. J. (2004). Managing in complex business networks. Industrial Marketing Management, 33, 175-183.

Roberts, J. H. (2000). Developing New Rules for New Markets. Journal of the Academy of Marketing Science, 28(1), 31-45.

Rudestam, K. E. \& Newton, R. R. (1992). Surviving Your Dissertation: A Comprehensive Guide to Content and Process. Newbury Park: Sage.

Schultz, D., Kerr, G. F., Kim, I. \& Patti, C. (2007). In search of a theory of integrated marketing communication. Journal of Advertising Education, 11(2), 21-31.

Smith, M. F., Sinha, I., Lancioni, R. \& Forman, H. (1999). Role of Market Turbulence in Shaping Pricing Strategy. Industrial Marketing Management, 28, 637-649.

Smith, A. (2002). Three scenarios for applying chaos theory in consumer research. Journal of Marketing Management, 18, 517-31.

Stacey, R. D. (1992). Managing Chaos. London: Kogan Page.

Stacey, R. D. (1995). The science of complexity: An alternative perspective for strategic change processes. Strategic Management Journal, 16, 477-495.

Stacey, R. D. (1996). Complexity and Creativity in Organizations. San Francisco: Berrett-Koehler.

Van Uden, J. (2005). Using complexity science in organization studies: A case for loose application. Emergence, Complexity \& Organization, 7(1), 60-66.

Varey, R. J. (2004). The Orthodoxy and Hegemony of 'Marketing Communications': From Interactive Communication to Communicative Interaction. International Journal of Applied Marketing, 1(2) Available at: http://www.managementjournals.com/journals/marketing/vol1/3-1-2-2.pdf [Accessed December 6, 2013].

Welman, J. C. \& Kruger, S. J. (1999). Research Methodology for the Business and Administrative Sciences. Cape Town: Oxford University Press.

Wilkinson, I. F. (2003). On generalising: seeing the general in the particular and the particular in the general in marketing research. Paper presented at the Australia New Zealand Marketing Academy Annual Conference (ANZMAC), University of South Australia, 1-3 December.

Wilkinson, I. F. (2006). The evolution of an evolutionary perspective of B2B business. Journal of Business \& Industrial Marketing, 21(7), 458-465.

Williams, M. (1994). Interactive Marketing: How to use integrated offer-driven advertising, data-base marketing and sales promotion to create maximum action. Sydney: Prentice Hall.

Wollin, D. \& Perry, C. (2004). Marketing management in a complex adaptive system: An initial framework. European Journal of Marketing, 38(5/6), 556-572.

Yadav, N., Swami, S. \& Pal, P. (2006). High Technology Marketing: Conceptualization and Case Study. VIKALPA, 31(2), 57-74.

Yin, R. K. (2003). Case Study Research - Design and Methods, 3rd ed. Beverly Hills, CA: Sage Publications. 